\title{
What Works? Family Influences on Occupational Aspirations among Descendants of Middle Eastern Immigrants on the Swedish Labour Market
}

\author{
Pinar Aslan* \\ Department of Social Work and Psychology \\ The Faculty of Health and Occupational Studies \\ University of Gävle \\ Email: Pinar.Aslan@hig.se
}

\section{Nader Ahmadi}

The Swedish Agency for Work Environment Expertise

Nader.ahmadi@mynak.se

\section{Stefan Sjöberg}

Department of Social Work and Psychology

The Faculty of Health and Occupational Studies

University of Gävle, Sweden

Stefan.sjoberg@hig.se

\section{Eva Wikström}

Department of Social Work

Umeå University, Sweden

Eva.wikstrom@umu.se

${ }^{*}$ Corresponding author 


\begin{abstract}
In this article, we examine family influences on occupational aspirations among employed descendants of Middle Eastern immigrants. Using a qualitative approach, we conducted 21 semi-structured interviews with native-born descendants of Middle Eastern immigrants. We present and analyse their interpretations of their parents' experiences and living conditions before, during and after migration and demonstrate how these interpretations shaped their own occupational aspirations. We discuss parents' high expectations of their children in relation to ethnic-community valuations of educational and occupational achievements. These high expectations may increase the chances of social mobility but can also become a negative pressure, especially if parents set high standards but cannot help their children to meet those expectations. In these cases, older siblings who possess valuable knowledge of the educational system and labour market can function as important transferrers of resources.
\end{abstract}

Keywords: Labour market participation, descendants of immigrants, family relations, social capital, cultural capital

\title{
Introduction
}

In almost every Western European country, descendants of immigrants are generally in a less favourable labour-market position than descendants of natives (Gorodzeisky \& Semyonov, 2017; OECD, 2017). Nordic governments are aware that the social exclusion of individuals with an immigrant background is a substantial risk to social cohesion, and so tackling the social exclusion of those individuals is a high-priority goal in the Nordic countries (Nordiska ministerrådet, 2012). Labour-market inclusion is an important step towards realizing this goal, and several steps have been taken to increase the educational and occupational integration of individuals with an immigrant background (Government Offices of Denmark, 2016; Government Offices of Sweden, 2015; Norwegian Government Offices, 2016).

Individuals with non-Western backgrounds (i.e., outside Western Europe and North America) face particular challenges in entering and participating in the labour market (Heath, 2010; Segendorf \& Teljosuo, 2011; Statistics Sweden, 2010). The gaps between immigrants and the native-born population in unemployment, employment rates and earnings are generally greater for nonWestern immigrants and their descendants than for those of Western ancestry (Hermansen, 2013; Schröder, 2010; Statistics Sweden, 2010). As Zhou and Kim 
(2006) emphasize, some immigrant groups face less favourable 'opportunity structures' in the host society than others. Among these groups, non-Western immigrants are most subjected to disadvantageous opportunity structures (Liebig \& Widmaier, 2009).

Previous studies have emphasized the intergenerational transmission of social exclusion and negative labour-market outcomes among non-Western immigrants and their children (Rooth \& Ekberg, 2003; Sernhede, 2007; Solon, 1999). Factors such as class background, discrimination against the ethnic group, the social and economic incorporation of pre-existing ethnic communities and the welfare-state arrangements of the receiving country affect opportunities for labour-market participation by non-Western immigrants and consequently the resources they are able to transmit to their children (Kim \& Zhou, 2006). Previous studies have shown that individuals with non-Western immigrant parents generally have lower employment rates and lower earnings, are in lessqualified occupations and tend to be less well equipped with resources that are valuable on the labour market (Behtoui, 2006; Crul \& Mollenkopf, 2012).

Nevertheless, many studies show that non-Western immigrant parents often have high expectations of their children in terms of educational and occupational attainment, regardless of social background (Feliciano \& Lanuza, 2016; Hofferth \& Moon, 2016; Taylor \& Krahn, 2013). These high expectations can be seen as an element of migration biographies. The concept of migration biographies describes a connection between the experiences and living conditions of immigrants before, during and after migration, which influence the adaptation of both immigrants and their children to host societies (Crivello, 2015; Spierings, 2015). As pointed out by Louie (2004, p. 123), children 'become both witnesses and participants in the migration process'; their lives are affected by the difficulties and challenges their parents face on account of migration. Ethnic discrimination, less-extensive social networks and exclusionist labour-market structures put many non-Western immigrants in a vulnerable position on the labour market (Arai \& Vilhelmsson, 2004; Behtoui, 2006; Lemaître 2007). As a result, many of them are socially excluded and experience a loss of status after migration (Gang \& Zimmermann, 2000; van Ours \& Veenman, 2003). The high expectations of non-Western immigrant parents may derive from an ambition to help their children compensate for this loss of status and to make the sacrifices of migration worthwhile (Dreby \& Stutz, 2012). Immigrant parents from nonWestern countries, including those of working-class background in the home country and with no formal education, often express an 'immigrant optimism' in entering a new country, expecting their children to make use of new educational 
and occupational opportunities (Louie 2004; 2012). Non-Western immigrant parents' expectations for their children to inherit family ideals and exhibit upward mobility may be viewed as part of collectivist family systems. Collectivism here refers to a high degree of interdependence between individuals in a group that exhibits a sense of mutual obligation and of attending to the needs of others in forming and accomplishing goals (Hofstede, 1980; Rudy \& Grusec, 2006). This is in contrast to the concept of individualism, which valorises individual autonomy in relation to group belonging. In countries with comprehensive and developed welfare states, such as Sweden, individualism has been described as an institutionalized mechanism of everyday life (Beck \& Beck-Gernsheim, 2009), whereas places with less-developed welfare institutions, as in the Middle East, have more collectivistic relations and value systems (Ahmadi, 1998; Ayçiçegi-Dinn \& Caldwell-Harris, 2011; Hofstede, 1980). With increased globalization, however, the understanding of an individualism/collectivism dichotomy ought to be relational rather than fixed in regard to countries and cultures (Rothbaum \& Trommsdorff, 2007). As Hofstede (1980) argues, the individualist and collectivist value systems should not be understood as systems coupled with specific geographical locations but rather as being dependent on situation and context. In societies in which the welfare state is relatively weak, people more often depend on one another and form strong, cohesive in-groups. In societies in which the state takes responsibility for citizens' welfare, relationships between individuals are comparatively looser and people more autonomous. The individualism/collectivism dichotomy should be seen as poles of a continuum that people move between in distinct societies, depending on social settings (cf. Grønseth, 2010).

Collectivist values can contribute to the social mobility of the descendants of immigrants, as values placed on upward mobility may compel these individuals to pursue higher education and occupational attainments (Phalet \& Schönpflug, 2001), but collectivist values may also result in intergenerational value discrepancies and force descendants of immigrants to negotiate between an individualistic outer space and collectivist family values (Merz, Özeke-Kocabas, Oort, \& Schuengel, 2009). While parents' high expectations may increase their children's opportunities for educational attainment (Feliciano \& Lanuza, 2016), there is also the risk of transferring unrealistic expectations in light of the structural obstacles that descendants of immigrants face in school and on the labour market (cf. Lindgren, 2016).

In this study, we focused on these factors from the perspective of the descendants of Middle Eastern immigrants - that is, individuals born in Sweden, 
both of whose parents immigrated from the Middle East. The birth countries of the parents were Turkey, Iraq, Syria, Palestine, Pakistan and Lebanon. One relevant feature of these countries is that, due to having less-developed welfare states, they represent a category of countries that, in comparison to Sweden, exhibit a higher degree of collectivism as regards social relations and family value systems (Ayçiçegi-Dinn \& Caldwell-Harris, 2011; Hofstede, 1980). This enabled us to analyse the implications of collectivist features that characterise the social contexts of our participants.

In addition, as a group, these individuals face many similar challenges. Like many others with a background in non-Western countries, individuals with a Middle Eastern background are at risk of social and economic exclusion in Sweden (Gorodzeisky \& Semyonov, 2017; Statistics Sweden, 2010; Westin, 2015). We also know that negative attitudes among Swedes are most frequently directed against those with a background in the Middle East (Ahmadi \& Palm, 2018; Ahmadi, Palm, \& Ahmadi, 2016) and that these individuals face discrimination in recruitment (Carlsson, 2010). There is a possible link between the increased negative attitudes against Middle Eastern individuals and worldwide social and political developments related to the Islamic State and fear of terrorism. This is underscored by a recent study describing increased negative attitudes against Muslims in Sweden (Ahmadi \& Palm, 2018). In light of the disadvantaged situation that these individuals face as a group, it is important to study influences on their labour-market participation. This is particularly important considering that, due to conflicts in the Middle East, descendants of Middle Eastern immigrants are a fast-growing group in the Nordic countries.

Many earlier studies have focused on the labour-market exclusion of descendants of immigrants. In this study, in order to investigate the influences on their labour-market participation, we chose to focus on individuals who had entered the labour market. We consider this to be an important subject today, as Sweden and many other countries are seeking ways to promote labourmarket integration of immigrants and their children.

This article aims to examine family influences on occupational aspirations among Middle Eastern immigrants' descendants who are in employment. The concept of aspiration deals with participants' ambitions in reaching their occupational goals. We focus on the perceptions of the descendants of Middle Eastern immigrants because individuals' aspirations are affected by modes of 
perception - that is, views, assessments, and feelings (cf. Emirbayer \& Williams, 2005). We posed two research questions:

1) How do perceptions of parents' migration biographies influence the occupational aspirations of descendants of Middle Eastern immigrants?

2) How do family members influence the occupational aspirations of descendants of Middle Eastern immigrants?

\section{The production and re-production of cultural capital in a context of migration}

In analysing our material, we used the concept of cultural capital introduced by French anthropologist Pierre Bourdieu (1986). According to Broady (1998), cultural capital consists of symbolic resources that are acknowledged and sought by the majority but are available only to some, as they are handled by institutions with specific entry requirements. As such, cultural capital can be seen as resources that allow entrance and integration into widely recognized institutions, such as the educational system and the labour market. This type of capital is therefore highly regarded in society as a whole and organizes relations of dominance (Dumais, 2002; Stempel, 2005).

Our definition of cultural capital is that it (1) takes the form of qualifications, skills and formal or informal knowledge used to gain ground on the labour market, (2) may come in the form of the possession of objects that verify these qualifications, skills and knowledge and (3) is of a relational character, meaning that the value of these acquirements depends on the context in which they were produced, deployed and employed (Nohl, Schittenhelm, Schmidtke, \& Weiss, 2014). Thus, cultural capital comes in three forms: (1) an embodied state, as engraved dispositions of thought, behaviour and taste; (2) an institutionalized state, as credentials and qualifications acquired in widely recognized institutions; (3) an objectified state, as objects that verify these credentials and qualifications (Holt, 1998; Jæger \& Breen, 2016).

An embodied form of cultural capital that was acquired in the home country can be maintained among immigrant parents even after migration. Cultural capital in its institutionalized form might lose value after migration because the institutions that grant qualifications and credentials are subject to distinct laws regarding the evaluation and production of cultural capital (Bourdieu \& Passeron, 1979). In its embodied form, however, as engraved dispositions of 
thought, behaviour and action in the minds and bodies of individuals, cultural capital can be preserved (Gordon \& Liu, 2015; Robb, Dunkley, Boynton, \& Greenhalgh, 2007; Panda, 2012). In the present study, the transmission of these embodied forms of cultural capital from parents to their children was discerned through the interpretations of the children. Following this line of thought, we considered the participants' interpretations of their parents' migration biographies and accumulation of symbolic resources in relation to conditions, situations and contexts.

An important aspect of accumulating cultural capital is support of others. Bourdieu (1986) emphasizes that resources do not necessarily lead to attainment; for this to occur, resources must be mobilized through the support of family, friends and relatives. He does not, however, elaborate on the type of support that allows for production of cultural capital. In relation to this, we considered active transmissions of cultural capital within the family (cf. Jæger \& Breen, 2016) - that is, formal and informal forms of knowledge, skills and qualifications among family members transmitted to descendants of Middle Eastern immigrants.

Finally, we also considered the accumulation of cultural capital by using resources other than existing cultural capital in the family. Researchers have argued that the socioeconomic situation of parents tends to be transmitted to their children. While this is true at a general level, this line of thought is problematic when considering the descendants of immigrants who exceed the socioeconomic situation of their parents (cf. Luthra \& Soehl, 2015; Luthra \& Waldinger, 2013). Against this background, we examined ways of producing cultural capital in relation to the intergenerational transmission of values as well as parental engagement, support and motivations as perceived by the descendants of Middle Eastern immigrants.

\section{Method}

Qualitative semi-structured interviews were conducted in September 2015 and January 2016 with 21 individuals (nine male, 12 female), all aged between 25 and 35 years and born in Sweden, with both parents born in Middle Eastern countries. Each interview lasted between 30 and 90 minutes.

Preliminary themes and interview questions were formulated on the basis of earlier research and the theoretical framework and were used tentatively to focus the interviews on the main areas of research. We used open-ended 
questions primarily in order to allow the discovery of unexpected areas of interest (Bryman, 2012). Among other things, we asked the participants to describe their families, the educational and occupational background of family members and the nature of their relationships with these individuals. We asked the participants about their employment and career aspirations and how they believed these matters were perceived and influenced by family members. These questions, along with others, provided information on the participants' interpretations of their parents' migration biographies and of influences from family members.

The participants chose the form of communication and the environment in which the interview took place. Some preferred to be interviewed in person $(n=7)$, while others preferred Skype or telephone interviews. Although some scholars have warned that virtual interviewing may inhibit a trustful interviewer/interviewee relationship (Fontana \& Frey, 2008), technological advances in recent decades have created a very similar environment between virtual interviewing and face-to-face interaction (lacono, Symonds, \& Brown, 2016). Because not all interviewees could attend a face-to-face interview and some were not sufficiently familiar with Skype, telephone interviews were offered as an alternative. Telephone interviews preclude observation of facial expressions and body language, but we aimed to compensate for this by explaining and asking for explanations in a more detailed manner. Providing various options of interviewing methods can be an advantage, as it increases participants' motivation for taking part in a study. All interviews were audio recorded and transcribed to written text.

The interviews were conducted, transcribed and analysed in Swedish. The quotations extracted from the transcripts and used to demonstrate findings in this article were translated from Swedish with the help of a native Englishspeaking professional. The interviews were conducted in Swedish by the first author, who has a Middle Eastern background but is fluent in the Swedish language. According to Fontana and Frey (2008), understanding the language and cultural background of the interviewees is important for qualitative interviewing. The Middle Eastern background of the interviewer thus increased our understanding of added nuances of meaning and cultural interpretations that might otherwise have gone unnoticed. These interpretations involved, for example, collectivistic features in the family and community. An awareness of how various situations were potentially influenced by collectivist aspects increased the possibility of detecting the undertones of the participants' descriptions and explanations, enabling relevant follow-up questions. In order 
to foster a reflexive research process, however, all four authors reflected on and analysed the data material in joint discussions.

\section{Sampling procedure}

Participants were initially recruited through advertising in social media. As this did not produce enough participants, an advertisement was placed in one of Sweden's largest cost-free newspapers, which reaches approximately 1.2 million individuals in central and southern Sweden. This led to a significantly larger sample size and allowed us to obtain a more varied sample with respect to social background, gender and parents' country of origin. As in most qualitative studies, this type of sampling methodology implies a self-selection bias; the recruitment of participants for the study becomes dependent on individuals' interest in participating in the study. Prior to expressing their interest in the study, the participants were informed that the study would deal with the labour-market participation of the descendants of immigrants. After expressing their interest in participating, they were given more detailed information about the research aim, the research questions and the interview themes. This limited a self-selection bias as regards the research questions.

The sample was purposeful, meaning that we recruited participants according to our research aim (Coyne, 1997). Our aim was to study family influences on occupational aspirations, and so all participants were employed and had been so for at least six months. We were not selective with respect to the educational and occupational backgrounds of the participants, but the majority of the individuals who expressed an interest in participating happened to be university graduates $(n=17)$; of the remainder, three had vocational training and one had completed secondary education. All of them had managed to enter the labour market, either in professional positions $(n=16)$, as managers $(n=2)$ or in other employed or self-employed work $(n=3)$. We are aware that our sample was biased, as we interviewed individuals who were already established on the labour market and not those who were unemployed; however, the influences that lead to labour-market exclusion for descendants of Middle Eastern immigrants were not the focus of this study.

Regarding parents' backgrounds, some of our participants had parents with neither an educational nor a working background in the host country, some had parents with no educational background but a high level of labour-market participation and others had highly-educated parents with a high level of labourmarket participation over time. Consequently, our sample gave us the 
opportunity to shed light on how resources are produced for individuals with various social backgrounds and to contextualize the question of intergenerational social mobility.

\section{Ethical considerations}

The ethical guidelines of the Swedish Research Council were taken into consideration at all stages of the research process. Before starting data collection, we were granted approval from the Regional Ethics Review Board (registration number 2015/025). Participants gave their consent after being informed of the aim and conditions of their participation, including anonymization of participants and the right to withdraw from the study at any time during the research process.

\section{Analytical strategy}

The interview recordings were transcribed and then analysed with an abductive thematic approach, meaning that we moved back and forth between theory and empirical findings (Dubois \& Gadde, 2002). We started by scanning the transcripts and searching for meaning units - that is, sections of the texts relevant to the research questions.

Coding was performed with version 7.5.4 of the ATLAS.ti computer software for qualitative data (Rambaree \& Faxelid, 2013). We reread the transcripts with the meaning units in mind and kept a codebook including the frequencies and meanings of as well as links between codes (Silverman, 2015). To bring structure to this list of codes, we created a 'network view' in ATLAS.ti, which is a graphical view of all the codes and the links between them. This network view allowed us to work visually, facilitating our analysis of the relationship between codes (cf. Friese, 2014) and the collecting of codes into themes. Four themes were found: parents as role models ( $n=9$ interviews); parental engagement and support ( $n=12$ interviews); active transmission of cultural capital by siblings ( $n=12$ interviews); and influences of collectivist values in the family and ethnic community ( $n=13$ interviews).

\section{Results}

In the sections that follow, we describe and discuss family influences on occupational aspirations, drawing on our interviews with the descendants of 
immigrants from the Middle East. We aimed not to represent such individuals as a collective but rather to analyse occupational aspirations in relation to figures and backgrounds, that is, interpretations of parents' migration biographies, family values and the accumulation of cultural capital in the family.

\section{Parents as role models}

The accumulation of cultural capital among these descendants of Middle Eastern immigrants was intimately bound up with notions of possibilities and obstacles on the labour market. When achieved occupational attainments are common in a family, it becomes natural for children in that family to believe that it is possible for them to attain the same (cf. Bourdieu \& Passeron, 1979). This circumstance was in play for our participants, but notions of possibilities were contextual and derived from their interpretations of their parents' migration biographies. The participants described their parents as individuals who had managed to obtain favourable labour-market positions despite facing difficulties on the labour market, which became a motivational force for the participants. One example of this outlook appeared in an interview with a 26-year-old selfemployed man [IP11]. His parents had migrated to Sweden in the 1970s and, despite lacking educational credentials, had managed to find stable jobs in the host country as a special pedagogue and a nursery school teacher. The participant considered this a great accomplishment:

IP11: They came to Sweden with nothing, really - and they managed to build a safe environment for the whole family in a society where they didn't even speak the language. This is what has inspired and sustained me now [that] l'm an entrepreneur. What matters and what has inspired me is that nothing is impossible, and you can go wherever you want if you struggle hard.

This participant [IP11] assessed his parents' occupational attainments in relation to a wider context: to a history characterized by migration and by his parents' achievements in relation to difficulties in the host country, specifically, language barriers. These findings suggest that interpretations of parents' migration biographies can create a vision of opportunities for descendants of Middle Eastern immigrants. The production of cultural capital, then, does not necessarily occur as a direct effect of parents' educational and occupational positions but may also occur in light of the circumstances in which those positions are acquired. Witnessing their parents' going through difficulties while still managing to achieve occupational goals led to the drive and ambition required to overcome structural difficulties of their own. The participants perceived their parents as role models, not necessarily in terms of wanting to 
achieve the same occupational position as them but in the sense of overcoming difficulties. This was further illustrated by a 25-year-old male café owner [IP19] whose parents had migrated to Sweden in the late 1980s. His mother was unemployed throughout his childhood, but he described how his father had managed to achieve economic success after years of hard work:

IP19: If I had to name someone [as my role model], it'd be my dad. My dad came to Sweden with no job, seven children, not knowing the language, nothing. He got a job as a dishwasher and managed to go from that to opening a grill, then a pizzeria, then starting more businesses and expanding to become a wholesaler.

The participants described their relations with their parents as being pervaded by a sense of pride and inspiration derived from perceptions of their parents' migration biographies. This suggests that assessments of parents' migration biographies enable an intergenerational transmission of resources. The participants described their parents' occupational accomplishments as a reference point when assessing their own opportunities on the labour market. $A$ similar pattern emerged among participants with parents who had obtained higher educational diplomas before migration and hence faced the risk that those educational credentials and work experiences would be less valued in the host country than in the home country (Gang \& Zimmermann, 2000). When describing influences on their own occupational aspirations, the participants highlighted their parents' occupational accomplishments in relation to this risk. The driving force of the intergenerational transmission of cultural capital was more properly the conditions surrounding the accumulation of resources than the resources themselves. This was evident in an interview with a 28-year-old woman [IP22] who worked as a manager at a residential-care home. Her mother was a psychiatrist prior to migration and had managed to find jobs in line with her educational degree:

IP22: My biggest inspiration is her [the mother]; she came to Sweden not speaking the language, and with a foreign degree, but she struggled hard. And now she's one of the best in her line of business.

The outlook presented by the participant above [IP22] sheds light on the relational character of cultural capital. Interpretations of parents' resources and difficulties in relation to migration again allowed for an intergenerational transmission of cultural capital. Here, migration became a form of capital in itself, which activated the transmission of an embodied form of cultural capital from parents to children. The parents' accomplishment in transforming an embodied form of cultural capital (that was accumulated in the home country) into an institutional form of cultural capital in the host country became a source 
of inspiration for the participants. Interpreting their parents' migration biographies as examples of overcoming difficulties on the labour market motivated the participants and gave them confidence; they believed that, if their parents had managed to enter the labour market despite a difficult position as migrants, it was certainly possible for them, as they did not have language barriers to overcome and their educational credentials were not 'foreign'.

This optimism regarding upward mobility, projected to them via parents, sometimes contrasted with the structural difficulties that the descendants of Middle Eastern immigrants faced. A 27-year-old male teacher [IP10], whose parents had both managed to enter the labour market soon after arriving in Sweden, gave one example of such an experience. The man's parents had a long experience of labour-market participation in the host country, and at the time of the interview his mother worked as a professional Arabic interpreter and his father at a residential-care home for unaccompanied refugee children. His parents had optimistic expectations of the host country, which had been communicated to him since he was a child. He described how both of them had imprinted on him a sense that everything is possible in Sweden, especially with a university education, but he reflected on how his ethnic background sometimes became a hindrance to him despite his educational credentials:

IP10: It's sad when you have to confront your parents by saying 'You were wrong'. Sometimes, education doesn't help; you could be qualified for a job but be passed over because of your ethnic background. . . This is how I and many of my friends felt. A degree increases our odds, of course, but they're never equal to the odds of native children.

While parental achievements were a source of inspiration and motivated the participants in terms of educational and occupational aspirations, these achievements could also become a source of stress. This was especially the case among the participants who experienced a negative pressure from their parents. An example of this was seen in an interview with a 25-year-old female psychologist [IP8]. Upon migration, her father possessed a degree in psychology education and her mother a degree in industrial design engineering. The participant described how both her parents had attained labour-market positions in the host country that corresponded to their educational background, although only after overcoming many obstacles. During the interview, she reflected on how her parents' attainments put pressure on her and her sister:

IP8: We had to aspire to a high-status job, which requires higher education.... And when I studied theatre and literature alongside my psychology classes, my dad was like 'I can't sleep at night'. ... It was the 
same for my sister; she obtained a bachelor's degree in economics . . but then was like, 'I didn't even want to do this. I wanted to become a teacher'.

The participants felt a sense of obligation to fulfil their parents' expectations in terms of educational and occupational attainments. However, these expectations were not always in harmony with their own interests. When this was the case, parental expectations contributed to an accumulation of cultural capital but did not necessarily lead to a sense of personal fulfilment among the participants.

\section{Parental engagement and support}

Many of our participants had surpassed the socioeconomic positions of their parents. They assessed their parents' positions on the labour market as having been limited by a lack of opportunities due to migration, but they had optimistic attitudes regarding their own occupational attainments. These participants emphasized that their parents had pushed them towards educational and occupational ambitions, which they believed had contributed to their attainments. Parental involvement in the form of moral support and encouragement thus became a family resource that contributed to the production of cultural capital. Surpassing the socioeconomic position of parents occurred through an accumulation of cultural capital, which was fostered by intergenerational values put into education and by interpretations of parents' migration biographies. This was illustrated by a 25 -year-old male compliance specialist working at a bank [IP7], whose parents had migrated to Sweden in the late 1980s with no educational background. During his upbringing, his father had been chronically ill and his mother long-term unemployed. He described his parents as being a driving force in his own accumulation of cultural capital:

IP7: My dad, he always encouraged us to study . . . because he never had the chance himself. And mum too, she was so supportive. ... When I decided to become a lawyer, they were like, 'Always do more'.... They couldn't help me do it, but they pushed me.

Sania Ali, Dahlstedt and Hertzberg (2018) have described how the labourmarket exclusion of immigrant parents is not always reproduced in the next generation but can have the reverse effect by encouraging children to strive to 'compensate' for their parents' difficulties. Some of the participants in this study described their own labour-market attainments as a compensation for their parents' lack of opportunities. This outlook was mediated to them by their parents, as illustrated by a 32-year-old man [IP16] working at the employment office: 
IP16: I think, because mum was illiterate, she's had an inferiority complex for a long time. She's tried to learn but failed. So, she's pushed me and my younger brother, like, 'Make something of your lives; study, be independent, don't go into the restaurant business'. Dad was the same, like, 'Don't follow in our footsteps', so I think we got a lot of this from our parents.

The reversed influence of parents' educational and occupational positions was fostered by interpretations of the parents' migration biographies, which inhabited a context of time and place. The participants made a clear distinction between themselves and their parents in terms of structural opportunities, and it was this differentiation that allowed for the reversed influence. This was illustrated by a 32-year-old teacher [IP5] who explained why he had abandoned his undesirable lifestyle and finished his secondary education after years of falling behind:

IP5: My father and I, we sat down and talked. And we sort of connected when he told me about how he wished he'd had the educational opportunities that I had in Sweden. He told me how precious it was in comparison... and, like, I gained some perspective.

As highlighted in the introduction, the descendants of Middle Eastern immigrants may feel a responsibility to 'climb the social ladder' in order to justify their parents' migration-related sacrifices. Among our participants, this outlook fostered a sense of obligation to acknowledge and make use of opportunities that their parents did not have; thus, the descendants' occupational aspirations were ambitious and involved plans for social mobility. These findings suggest that parental involvement, regardless of socioeconomic status and social background, can contribute to the accumulation of cultural capital. Nevertheless, active transmission of cultural capital in the home is important for the accumulation of such capital. It may be difficult for the descendants of Middle Eastern immigrants to fulfil their parents' high expectations if the parents push their children but cannot help. In the next section, we show that active transmission of cultural capital can come via siblings instead of parents and that such transmission may compensate for the parents' lack of assistance in schoolwork and labour-market participation.

\section{Active transmission of cultural capital by siblings}

Having successfully negotiated the educational system and gained access to the labour market, some of our participants' older siblings had accumulated cultural capital that could be transferred within the family. Siblings provided homework assistance as well as support and recommendations related to 
labour-market participation, from filling out CVs to giving advice on how to behave during an interview. When parents fell short in terms of giving tangible forms of support, siblings played a role in filling the void and became an important source of cultural capital. This was exemplified by a 32-year-old male teacher [IP5] and a 25-year-old male economist [IP20]:

IP5: My sister helped me with my homework whenever I needed help . . . When I went to my first job interview . . . my brother told me how to behave, like, 'Look the recruiter in the eye, give a firm handshake, try to answer the questions honestly'.

IP20: It was more or less my sister who helped me make the right choice. . . I I don't think they [the parents] understood. Should I choose social science? Should I choose tech? They don't know the difference . . . I knew my sister wanted what's best for me, and she had the knowledge, so she was the one I turned to.

In an interview with the 25-year-old compliance specialist [IP7] mentioned in the previous section, it appeared that his parents set high standards in regard to educational attainments but could not help him meet those standards. His older siblings, on the other hand, had qualifications, skills and both formal and informal knowledge in relation to school and the labour market, which they transmitted to the younger brother:

IP7: My brothers helped me. When I was four years old, for example, they taught me the multiplication table, so when I started school, the teachers considered me a genius.... They helped me [after graduation], even though they didn't know as much about the labour market as Swedish parents.

The quotation above illustrates how active transmission of cultural capital by siblings could be converted into educational performance as well as occupational attainments, thereby enabling further accumulation of cultural capital by these descendants of Middle Eastern immigrants. Similar findings have been presented by Crul, Holdaway, De Valk, Fuentes \& Zaal (2013), who showed that older siblings in immigrant families often provide advice as well as emotional and practical support to their younger siblings in their educational careers. Here, we show that such support may help descendants of Middle Eastern immigrants to form occupational aspirations and to realize those aspirations.

\section{Influences of collectivist values in the ethnic community}

In the earlier sections of this article, we described perceptions of high parental expectations among our participants and a sense of obligation to fulfil those 
expectations. This can be better understood in relation to participants' descriptions of collectivist values in their families and their ethnic communities. In this section, we highlight ways of producing cultural capital in relation to these collectivist values. A symbolic value was placed on educational and occupational attainments in the ethnic communities of the participants and their parents; people who managed to 'make something of themselves' were respected and highly valued. Against this background, the participants described their parents' expectations as, on the one hand, based on hopes of a better future for their children but, on the other, representing a desire to obtain social status among ethnic-group peers. Participants' descriptions of their occupational aspirations were infused by a desire to make their families proud and obtain social status. One 35-year-old woman [IP12], who had just been promoted to manager at a wood-processing company, illustrated how such collectivistic values could intensify the desire to ascend on the labour market:

\begin{abstract}
IP12: You want your family to be proud of you, to acknowledge that you've done something of value. ... My husband, my parents, my relatives, my family ... I think it makes them respect you somehow. Some of it might be a cultural thing.... In my family, they've always considered me a person worth listening to. People come to me and ask for my opinion on different things. This is very important to me.
\end{abstract}

The quotation above suggests that accumulation of cultural capital, in the form of educational credentials and access to valued labour-market positions, can organize relations of power in the family and among relatives because others consider the participant to be a person 'worth listening to'. These findings suggest that it is possible to accumulate cultural capital through extra efforts that are inspired by intergenerational values placed on education and occupational attainment and by a quest for increased individual agency. Obtaining a job that the community considered 'good' increased the status of parents as well as children, as illustrated by a 25 -year-old woman [IP4] working in social services:

IP4: It sounds good to say to friends, 'My daughter works in social services'. It was considered a high-status thing to work at an administrative authority. They felt like, 'We've succeeded because our daughter got a degree and a good job'. So, it's a status thing.

The occupational aspirations of the participants were influenced by an interdependence with family members and other members of their ethnic community. This was exemplified by a 26-year-old man [IP13] who described why it was so important to his parents that he went to university and by a 32year-old man [IP5] who, after years of struggling in school and having casual 
jobs, eventually got a teaching degree and perceived a shift in how family members and members of his ethnic community treated him after he became a teacher:

IP13: I think a lot of this [getting a degree] is because, in our ethnic community, they like to brag about their children. And if you have something to be proud of, you can absolutely brag about it.

IP5: My mum, she liked to tell her friends about me ... our culture is a lot about living as a community ... with neighbours, relatives, and so on ... and they talk about what their sons do. Before, she never talked about what I do, but now it's like, 'XX does this'. Relatives phoned me up and said they were proud ... such things encouraged me ... and still, when I meet people in the street, they greet me by saying 'Hello, ustad', which means 'teacher' in Arabic. They say that as a way of showing respect in the home country ... you don't address teachers by name; you call them 'teacher'.

Portes and Zhou (1993) discuss possibilities of social mobility among descendants of immigrants with respect to parents' expectations and to ethnic communities. They argue that, in light of their subjection to discrimination and unequal access to resources in host societies, immigrants' children may have a better chance of educational and occupational attainments by remaining integrated within ethnic communities with achievement orientations and high levels of group solidarity. The results presented here are in line with these arguments and suggest that the collectivist values of the family and ethnic community may contribute to an accumulation of cultural capital among descendants of Middle Eastern immigrants. As indicated by our 25-year-old compliance specialist [IP7], however, such orientations can also have a negative impact:

IP7: I chose to become a lawyer, and that was only considered 'okay' . . . it wasn't 'wow' to them. ... My brother was a lawyer, so they already had a lawyer. They wanted me to be a doctor; they talked about that all the time.

While our findings support the argument presented by Portes and Zhou (1993), they also demonstrate that a strong orientation towards achievement may lead to feelings of inadequacy among descendants of immigrants. Findings presented by Bankston and Zhou (2002) illustrate a similar pattern, with children of Asian immigrants showing high levels of school performance but low levels of self-esteem. Thus, although an interdependence between family members and a high level of ethnic solidarity may increase descendants' chances of achieving occupational attainments, this needs to be considered in relation to aspects of personal wellbeing. 


\section{Conclusion}

In this study, we examined family influences on the occupational aspirations of descendants of Middle Eastern immigrants in Sweden who have managed to enter the labour market. Our results indicate that intergenerational transmission of cultural capital in the family positively influences the occupational aspirations of descendants of Middle Eastern immigrants and that perceptions of parents' migration biographies are important in acquiring cultural capital. We discovered that an embodied form of cultural capital was deployed in the transmission process in terms of thoughts, behaviours and actions related to parents' educational and occupational backgrounds prior to migration. These embodied forms of cultural capital contributed to the accumulation of institutionalized and objectified forms of cultural capital among descendants of Middle Eastern immigrants in the form of credentials from the educational system and the labour market and objects that verify those credentials. Active transmission of cultural capital, in terms of sharing knowledge, attitudes and practices, occurred mainly between siblings, who filled the void when parents lacked the ability to provide substantial support.

Parents' pivotal role in shaping and supporting the participants' occupational aspirations was manifested through the participants' perceptions of their parents' migration biographies. Our empirical results suggest that the accumulation of cultural capital among descendants of Middle Eastern immigrants occurs mainly in relation to three aspects of the parents' migration biographies. First, there is the parents' ability to transform an embodied form of cultural capital, acquired in the home country, into an institutionalized form in the host country. This allowed the participants to see possibilities and motivated them to put in extra effort, believing that if their parents could 'make it' with fewer resources than themselves, so could they, despite facing structural obstacles on the labour market. Thus, parents' migration biographies may become a source of resilience for descendants of Middle Eastern immigrants when they face negative treatment and discrimination on the labour market.

Second, our empirical results demonstrate a desire to 'make up' for parents' lack of opportunities in the host country and to compensate by obtaining prestigious positions. Obtaining these positions also strengthened participants' positions of power in the family, which further contributed to their occupational aspirations. Here, the accumulation of cultural capital was induced by a strong drive and ambition. The intergenerational values placed on educational and occupational attainment as a result of the migration process have been 
discussed by other scholars in relation to the so-called 'immigrant bargain' (cf. Crul, Schneider, Keskiner, \& Lelie, 2017; Louie, 2004; 2012). The concept of the immigrant bargain describes immigrant parents' expectations of the host country in relation to their children's occupational attainments.

Third, and related to the former two aspects, we found that parents' migration biographies were infused with collectivist values that propelled parents' engagement and support as well as their desire to obtain social status through the participants' accumulation of cultural capital.

Some of our findings also indicate negative family influences. Parents' high expectations and a sense of obligation to the family may lead to feelings of distress for the descendants of Middle Eastern immigrants, especially when those expectations are not in line with the descendants' own desires and interests and when they are hindered by many structural obstacles to labourmarket attainment. An inconsistency between parents' high expectations and descendants' possibilities of meeting those expectations may be due to immigrant parents' optimism regarding their children's opportunities in the host country (cf. Kao \& Tienda, 1995). The details and implications of an inconsistency between immigrant parents' expectations of their children and their children's personal levels of wellbeing remain to be investigated.

While certain features in the transmission of cultural capital among our participants may also apply to descendants of the native born, we have demonstrated some aspects that distinguish descendants of Middle Eastern immigrants. The distinction here is not in the accumulation of cultural capital as such, but in why and how cultural capital is accumulated - that is, the mechanisms of accumulation. The motivation provided by the participants' perceptions of their parents' migration biographies and of collectivist values in the family helps explain how our participants, despite facing ethnic penalties on the labour market, had high occupational aspirations and managed to acquire cultural capital.

These aspects also expand our understanding of how cultural capital may be acquired regardless of a socioeconomically disadvantaged background. In studies researching the transmission of cultural capital within the family, the accumulation of cultural capital has generally been linked to parents' socioeconomic status (cf. Bodovski, Jeon, \& Byun, 2017; Redford, Johnson, \& Honnold, 2009). Our results concur with those of other studies that demonstrate that many descendants of immigrants exceed the socioeconomic status of their 
parents (Crul et al., 2017; Konyali, 2017; Luthra \& Soehl, 2015; Luthra \& Waldinger, 2013; OECD, 2016; Rezai, 2017). We suggest that the breaking of the 'reproduction cycle', i.e. of reproducing parents' socioeconomic status, is bound up with perceptions of parents' inclusion or exclusion in the host country, with active transmission of cultural capital in the family and with a collectivist value system. While some of our participants grew up in socioeconomically disadvantaged families and faced many obstacles in education and on the labour market, their parents' migrant trajectories implied expectations of social mobility. These expectations were shaped by collectivist values in the families and ethnic communities of the participants, implying that children's occupational attainments were a source of pride for the entire family. Such collectivist values propelled the transmission and accumulation of cultural capital between parents, siblings and the participants. As argued in the introduction to this article, collectivist family values may not be as explicit in native Swedish families, which are shaped more by individualistic value systems. Thus, we argue that, while the acquirement of cultural capital may follow the same procedures, the mechanisms that propel transmission and accumulation of cultural capital may differ in native-born and immigrant families.

In light of our results, we would like to see a sharper focus on the intergenerational aspect of immigrants' integration into the Nordic countries, especially considering scholars' discussions of how welfare-state arrangements influence labour-market participation by immigrants and their descendants (Bean et al., 2012; Crul \& Mollenkopf, 2012; Schröder, 2010). The possibility of converting migration biographies into a positive drive may be greatly affected by institutional arrangements of the welfare state. Some scholars have argued that 'generous' welfare-state contexts, such as in Sweden, create disincentives for immigrants to participate on the labour market, as they become dependent on welfare benefits (see, e.g., Koopmans, 2010). In contrast to such arguments, we have demonstrated a strong drive and ambition to achieve labour-market participation among the descendants of Middle Eastern immigrants in this study, projected to them via their parents. Our participants did not feel obliged to find work at the earliest opportunity, regardless of their parents' socioeconomic situations, but were encouraged to achieve their occupational aspirations. In an environment that protects the family from poverty, immigrants' descendants may prioritize the accumulation of cultural capital rather than simply finding a job at any cost. The implications of the welfare-state context on immigrant parents' approach to their children's labour-market participation has, however, not been the focus of this study and remains to be investigated. In order to 
investigate this further, future studies need to include interviews with immigrants' descendants who are excluded from the labour market. This may provide richer and more nuanced insights into how occupational aspirations may be linked to intergenerational aspects and the characteristics of diverse welfare-state contexts.

\section{References}

Ahmadi, F., \& Palm, I. (2018). Mångfaldsbarometern 2018. Gävle: Gävle University Press. Retrieved from https://www.hig.se/download/18.321e5b271641cca84643f3ba/1534110403023/ M\%C3\%A5ngfaldsbarometern_2018.pdf

Ahmadi, F., Palm, I., \& Ahmadi, N. (2016). Mångfaldsbarometern 2016. Gävle: Gävle University Press. Retrieved from http://hig.divaportal.org/smash/get/diva2:1085307/FULLTEXT01.pdf

Ahmadi, N. (1998). Om jaguppfattningens betydelse för tolkningen av sociala roller. In N. Ahmadi (Ed.), Ungdom, kulturmöten, identitet (pp. 56-87). Stockholm: Liber.

Arai, M., \& Vilhelmsson, R. (2004). Unemployment-risk differentials between immigrant and native workers in Sweden. Industrial Relations, 43(3), 690-698. https://doi.org/10.1111/j.0019-8676.2004.00355.x

Ayçiçegi-Dinn, A., \& Caldwell-Harris, C. L. (2011). Individualism-collectivism among Americans, Turks and Turkish immigrants to the U.S. International Journal of Intercultural Relations, 35(1), 9-16. https://doi.org/10.1016/j.ijintrel.2010.11.006

Bankston, C., III., \& Zhou, M. (2002). Being well vs. doing well: Self-esteem and school performance among immigrant and non-immigrant racial and ethnic groups. International Migration Review, 36(2), 389-415. https://doi.org/10.1111/j.17477379.2002.tb00086.x

Bean, F. D., Brown, S. K., Bachmeier, J. D., Fokkema, T., \& Lessard-Phillips, L. (2012). The dimensions and degree of second-generation incorporation in US and European cities: A comparative study of inclusion and exclusion. International Journal of Comparative Sociology, 53(3), 181-209. https://doi.org/10.1177/0020715212457095

Beck, U., \& Beck-Gernsheim, E. (2009). Losing the traditional: Individualization and 'precarious freedoms'. In A. Elliot \& P. du Gay (Eds.), Identity in Question (pp.1336). London: Sage. https://doi.org/10.4135/9781446213698.n2

Behtoui, A. (2006). Unequal Opportunities: The Impact of Social Capital and Recruitment Methods on Immigrants and Their Children in the Swedish Labour Market (Doctoral dissertation). Linköping University, Linköping. Retrieved from http://urn.kb.se/resolve?urn=urn:nbn:se:liu:diva-7789

Bodovski, K., Jeon, H., \& Byun, S. (2017). Cultural capital and academic achievement in post-socialist Eastern Europe. British Journal of Sociology of Education, 38(6), 887-907. https://doi.org/10.1080/01425692.2016.1202746

Bourdieu, P. (1986). The forms of capital. In J. Richardson (Ed.), Handbook of Theory and Research for the Sociology of Education (pp. 241-258). Westport, CT: Greenwood.

Bourdieu, P., \& Passeron, J. C. (1979). The Inheritors: French Students and Their Relation to Culture. Chicago: University of Chicago Press. 
Broady, D. (1998). Kapitalbegreppet som utbildningssociologiskt verktyg. [The Concept of Capital as a Tool for Sociology of Education]. Skeptronhäften/Skeptron Occasional Papers 15. Uppsala Universitet. https://www.divaportal.org/smash/get/diva2:328806/FULLTEXT01.pdf

Bryman, A. (2012). Social Research Methods (4th ed.). New York: Oxford University Press.

Carlsson, M. (2010). Experimental evidence of discrimination in the hiring of first- and second-generation immigrants. Labour: Review of Labour Economics \& Industrial Relations, 24(3), 263-278. https://doi.org/10.1111/j.1467-9914.2010.00482.x

Coyne, I. T. (1997). Sampling in qualitative research. Purposeful and theoretical sampling; Merging or clear boundaries? Journal of Advanced Nursing, 26(3), 623-630. https://doi.org/10.1046/j.1365-2648.1997.t01-25-00999.x

Crivello, G. (2015). 'There's no future here': The time and place of children's migration aspirations in Peru. Geoforum, 62, 38-46. https://doi.org/10.1016/j.geoforum.2015.03.016

Crul, M., Holdaway, J., De Valk, H.A.G, Fuentes, N., \& Zaal, M. (2013). Educating the children of immigrants in Old and New Amsterdam. In R. Alba \& J. Holdaway (Eds.), The Children of Immigrants at School: A Comparative Look at Integration in the United States and Western Europe (pp. 39-83). New York: NYU Press. https://doi.org/10.18574/nyu/9780814760949.003.0002

Crul, M., \& Mollenkopf, J. (2012). The second generation. In M. Crul \& J. Mollenkopf (Eds.), The Changing Face of World Cities: Young Adult Immigrants in Europe and the United States (pp. 3-25). New York: Russell Sage Foundation.

Crul, M., Schneider, J., Keskiner, E., \& Lelie, F. (2017). The multiplier effect: How the accumulation of cultural and social capital explains steep upward social mobility of children of low-educated immigrants. Ethnic and Racial Studies, 40(2), 321338. https://doi.org/10.1080/01419870.2017.1245431

Dreby, J., \& Stutz, L. (2012). Making something of the sacrifice: Gender, migration and Mexican children's educational expectations. Global Networks, 12(1), 71-90. https://doi.org/10.1111/j.1471-0374.2011.00337.x

Dubois A., \& Gadde, L. E. (2002). Systematic combining: An abductive approach to case research. Journal of Business Research, 55(2), 553-560. https://doi.org/10.1016/S0148-2963(00)00195-8

Dumais, S. A. (2002). Cultural capital, gender and school success: The role of habitus. Sociology of Education, 75(1), 44-68. https://doi.org/10.2307/3090253

Emirbayer, M., \& Williams, E. M. (2005). Bourdieu and social work. Social Service Review, 79(4), 689-724. https://doi.org/10.1086/491604

Feliciano, C., \& Lanuza, Y. R. (2016). The immigrant advantage in adolescent educational expectations. International Migration Review, 50(3), 758-792. https://doi.org/10.1111/imre.12183

Fontana, A., \& Frey, J. H. (2008). The interview: From neutral stance to political involvement. In N. K. Denzin \& Y. S. Lincoln (Eds.), Collecting and Interpreting Qualitative Material (pp. 115-160). California: Sage.

Friese, S. (2014). Qualitative Data Analysis with ATLAS.ti (2nd ed.). London: Sage.

Gang, I. N., \& Zimmermann, K. F. (2000). Is child like parent? Educational attainment and ethnic origin. Journal of Human Resources, 35(3), 550-569. https://doi.org/10.2307/146392 
Gordon, J. A., \& Liu, X. (2015). Bridging home and host country: Educational predispositions of Chinese and Indian recent immigrant families. International Journal of Multicultural Education, 17(3), 21-36. https://doi.org/10.18251/ijme.v17i3.1115

Gorodzeisky, A., \& Semyonov, M. (2017). Labor force participation, unemployment and occupational attainment among immigrants in West European countries. PLoS ONE, 12(5), 1-22. https://doi.org/10.1371/journal.pone.0176856

Government Offices of Denmark (2016). Samarbejde om bedre integration. Retrieved from https://www.fm.dk/ /media/publikationer/imported/2016/samarbejde-ombedre-integration/samarbejde-om-bedre-integration.ashx

Government Offices of Sweden (2015). Jämlik skola. Retrieved from http://www.regeringen.se/regeringens-politik/regeringens-prioriteringar/merkunskap-och-okad-jamlikhet-i-skolan/jamlik-skola/

Grønseth, A. S. (2010). Lost Selves, Lonely Persons: Experiences of Illness and Wellbeing among Tamil Refugees in Norway. London: Berghahn Books.

Heath, A. (2010). Main determinants of educational and labour market outcomes. In OECD, Equal Opportunities? The Labour Market Participation of the Children of Immigrants (pp. 115-127). Paris: OECD Publishing.

Hermansen, A. S. (2013). Occupational attainment among children of immigrants in Norway. Bottlenecks into employment - equal access to advantaged positions? European Sociological Review 29(3), 517-534. https://doi.org/10.1093/esr/jcr094

Hofferth, S. L., \& Moon, U. J. (2016). How do they do it? The immigrant paradox in the transition to adulthood. Social Science Research, 57, 177-194. https://doi.org/10.1016/j.ssresearch.2015.12.013

Hofstede, G. (1980). Culture's Consequences: International Differences in Work-Related Values. Thousand Oaks, CA: Sage.

Holt, D. B. (1998). Does cultural capital structure American consumption? Journal of Consumer Research, 25(1), 1-25. https://doi.org/10.1086/209523

lacono, V. L., Symonds, P., \& Brown, D. H. K. (2016). Skype as a tool for qualitative research interviews. Sociological Research Online, 21(2), 12. https://doi.org/10.5153/sro.3952

Jæger, M. M., \& Breen, R. (2016). A dynamic model of cultural reproduction. American Journal of Sociology, 121(4), 1079-1115. https://doi.org/10.1086/684012

Kao, G., \& Tienda, M. (1995). Optimism and achievement: The educational performance of immigrant youth. Social Science Quarterly, 76(1), 1-19.

Konyali, A. (2017). International opportunities on the way up: Alternative career paths of descendants of immigrants from Turkey in the field of professional business services. Ethnic and Racial Studies, 40(2), 264-282. https://doi.org/10.1080/01419870.2017.1245430

Koopmans, R. (2010). Trade-offs between equality and difference: Immigrant integration, multiculturalism and the welfare state in cross-national perspective. Journal of Ethnic and Migration Studies, 36(1), 1-26. https://doi.org/10.1080/13691830903250881

Lemaître, G. (2007). The integration of immigrants into the labour market: The case of Sweden. OECD Social, Employment and Migration Working Papers, No. 48. Paris: OECD Publishing. 
Liebig, T., \& Widmaier, S. (2009). Children of immigrants in the labour markets of EU and OECD countries: An overview. OECD Social, Employment and Migration Working Papers, No. 97. Paris: OECD Publishing.

Lindgren, J. (2016). Diaspora biographies balancing ideology and utopia: On future orientations of immigrant youth in a segregated Sweden: Preamble: Optics, young people's life trajectories and the school crisis. In G. B. Wärvik, C. Runesdotter, E. Forsberg, B. Hasselgren, \& F. Sahlström (Eds.), Skola, lärare, samhälle: vänbok till Sverker Lindblad (pp. 131-152). Göteborg: Göteborgs universitet.

Louie, V. (2004). Compelled to Excel: Immigration, Education and Opportunity among Chinese Americans. Stanford, CA: Stanford University Press.

Louie, V. (2012). Keeping the Immigrant Bargain: The Costs and Rewards of Success in America. New York: Russell Sage Foundation.

Luthra, R. R., \& Soehl, T. (2015). From parent to child? Transmission of educational attainment within immigrant families: Methodological considerations. Demography, 52(2), 543-567. https://doi.org/10.1007/s13524-015-0376-3

Luthra, R. R., \& Waldinger, R. (2013). Intergenerational mobility among immigrants and their descendants. In D. Card \& S. Raphael (Eds.), Immigration, Poverty and Social Mobility. New York: Russell Sage.

Merz, E.-M., Özeke-Kocabas, E., Oort, F. J., \& Schuengel, C. (2009). Intergenerational family solidarity: Value differences between immigrant groups and generations. Journal of Family Psychology, 23(3), 291-300. https://doi.org/10.1037/a0015819

Nohl, A. M., Schittenhelm, K., Schmidtke, O., \& Weiss, A. (2014). Work in Transition: Cultural Capital and Highly Skilled Migrants' Passages into the Labour Market London: University of Toronto Press.

Nordiska ministerrådet (2012). Den nordiska modellen i en ny tid. Program för Sveriges ordförandeskap i Nordiska ministerrådet 2013. Köpenhamn: Det nordiska samarbetet.

Norwegian Government Offices (2016). Jobbsjansen. Retrieved from https://www.regjeringen.no/no/tema/innvandring/integrering/introduksjonslov-ogarbeid/jobbsjansen/id2343473/

OECD (2016). Working Together: Skills and Labour Market Integration of Immigrants and Their Children in Sweden. Paris: OECD Publishing.

OECD (2017). Catching Up? Intergenerational Mobility and Children of Immigrants. Paris: OECD Publishing. https://doi.org/10.1787/9789264288041-en

Panda, M. (2012). Culture, discursive practices and literacy work in families: Why is mathematics important to Indian immigrants in UK? Psychology and Developing Societies, 24(2), 161-180. https://doi.org/10.1177/097133361202400204

Phalet, K., \& Schönpflug, U. (2001). Intergenerational transmission in Turkish immigrant families: Parental collectivism, achievement values and gender differences. Journal of Comparative Family Studies, 32(4), 489-504.

Portes, A., \& Zhou, M. (1993). The new second generation: Segmented assimilation and its variants. Annals of the American Academy of Political and Social Science, 530, 74-96. https://doi.org/10.1177/0002716293530001006

Rambaree, K., \& Faxelid, E. (2013). Considering abductive thematic network analysis with ATLAS.ti 6.2. In N. Sappleton (Ed.), Advancing Research Methods with New Technologies (pp. 170-186). Hershey, PA: IGI Global. https://doi.org/10.4018/978-1-4666-3918-8.ch010 
Redford, J., Johnson, J. A., \& Honnold, J. (2009). Parenting practices, cultural capital and educational outcomes: The effects of concerted cultivation on academic achievement. Race, Gender \& Class, 16(1/2), 25-44.

Rezai, S. (2017). Self-made lawyers? Pathways of socially mobile descendants of migrants from Turkey in Europe. Ethnic and Racial Studies, 40(2), 230-246. https://doi.org/10.1080/01419870.2017.1245433

Robb, N., Dunkley, L., Boynton, P., \& Greenhalgh, T. (2007.) Looking for a better future: Identity construction in socio-economically deprived 16-year-olds considering a career in medicine. Social Science and Medicine, 65(4), 738-754. https://doi.org/10.1016/j.socscimed.2007.03.011

Rooth, D.-O., \& Ekberg, J. (2003). Unemployment and earnings for second-generation immigrants in Sweden. Ethnic background and parent composition. Journal of Population Economics, 16(4), 787-814. https://doi.org/10.1007/s00148-0030163-0

Rothbaum, F., \& Trommsdorff, G. (2007). Do roots and wings complement or oppose one another? The socialization of relatedness and autonomy in cultural context. In J. E. Grusec \& P. Hastings (Eds.), The Handbook of Socialization. (pp. 461489). New York: Guilford Press.

Rudy, D., \& Grusec, J.-E. (2006). Authoritarian parenting in individualistic and collectivist groups: Associations with maternal emotion and cognition and children's selfesteem. Journal of Family Psychology, 20(1), 68-78. https://doi.org/10.1037/0893-3200.20.1.68

Sania Ali, S., Dahlstedt, M., \& Hertzberg, F. (2018). Arbete och övergångar. Viljan att bidra. In M. Dahlstedt (Ed.), Förortsdrömmar: Ungdomar, utanförskap och viljan till inkludering. Linköping: Linköping University Electronic Press.

Schröder, L. (2010). Labour Market Characteristics and Their Impact on the Integration of Immigrants' Offspring. Paris: OECD Publishing.

Segendorf, Å.-O., \& Teljosuo, T. (2011). Sysselsättning för invandrare - en ESO-rapport om arbetsmarknadsintegration (Report No. 2011:5) Retrieved from http://eso.expertgrupp.se/wp-content/uploads/2013/06/2011-5-till-webben.pdf

Sernhede, O. (2007). Alienation is My Nation: Hiphop och unga mäns utanförskap i Det nya Sverige. Stockholm: Ordfront.

Silverman, D. (2015). Interpreting Qualitative Data (5th ed.). London: Sage.

Solon, G. (1999). Intergenerational mobility in the labour market. In O. Ashenfelter \& D. Card (Eds.), Handbook of Labor Economics (Vol. 3). Amsterdam: Elsevier.

Spierings, N. (2015). Gender equality attitudes among Turks in Western Europe and Turkey: The interrelated impact of migration and parents' attitudes. Journal of $\begin{array}{llll}\text { Ethnic \& } \quad \text { Migration } \quad \text { Studies, } & \text { 41(5), }\end{array}$ https://doi.org/10.1080/1369183X.2014.948394

Statistics Sweden (2010). Born in Sweden - But Still Different? The Significance of Parents' Country of Birth. (Report No. 2010:2) Retrieved from http://www.scb.se/statistik/_publikationer/be0701_2010a01_br_be51br1002.pdf

Stempel, C. (2005). Adult participation sports as cultural capital. International Review for the Sociology of Sport, 40(4), 411-432. https://doi.org/10.1177/1012690206066170

Taylor, A., \& Krahn, H. (2013). Living through our children: Exploring the education and career "choices" of racialized immigrant youth in Canada. Journal of Youth Studies, 16(8), 1000-1021. https://doi.org/10.1080/13676261.2013.772575 
Westin, C. (Ed.). (2015). The Integration of Descendants of Migrants from Turkey in Stockholm: The TIES Study in Sweden. Amsterdam: Amsterdam University Press. https://doi.org/10.1515/9789048526956

van Ours, J. C., \& Veenman, J. (2003). The educational attainment of second-generation immigrants in the Netherlands. Journal of Population Economics, 16(4), 739-753. https://doi.org/10.1007/s00148-003-0147-0

Zhou, M., \& Kim, S. (2006). Community forces, social capital, and educational achievement: The case of supplementary education in the Chinese and Korean immigrant communities. Harvard Educational Review, 76(1), 1-29. https://doi.org/10.17763/haer.76.1.u08t548554882477 